\title{
17+1 COOPERATION: AN OVERALL ASSESSMENT ON CHINA-CENTRAL AND EASTERN EUROPEAN COUNTRIES RELATIONS
}

\section{Ahmet Eren ÜNCEL*

\begin{abstract}
Considering the steps taken by the Republic of China to lead the new world order with its 'go global' policy and the proximity of Central and Eastern Europe (CEE) countries to the world's largest market economy, the 17+1 initiative, which aims to invigorate the Belt and Road Initiative with CEE, has enormous potential. China has increased its trade volumes and improved economic relations with CEE countries in recent years and has backed up its targets with political and societal projects. However, due to various reasons, such as China's late engagement in the region and its incomplete infrastructure project, doubts exist as to whether China will reach its long-term targets. This article aims to draw attention to the potential of China's economic, political and societal relations with CEE in the context of the $17+1$ initiative by reviewing primary and secondary sources. The study elaborates on the 17+1 initiative in a descriptive and explanatory way and concludes that growing economic relations with CEE countries will not be single indicators of China's objectives but that China's concrete projects and willpower will be determinants of its objectives.
\end{abstract} Keywords: Central and Eastern Europe, European Union, China, Belt and Road Initiative, 17+1

JEL Codes: F34, F35, O52

\section{7+1 İŞ BİRLİĞİ: ÇİN-ORTA VE DOĞU AVRUPA ÜLKELERİ İLİŞKİLERİ ÜZERİNE GENEL BİR DEĞERLENDİRME}

\section{ÖZET}

Çin Halk Cumhuriyeti'nin 'go global' politikası ile yeni dünya düzenine öncülük etme yolunda attığı adımlar ve Orta ve Doğu Avrupa (CEE) ülkelerinin dünyanın en büyük piyasa ekonomisine yakınlığını göz önüne alındığında, CEE ülkeleri ile Kuşak ve Yol Girişimini canlandırmak isteyen 17+1 platformu muazzam bir potansiyele sahiptir. Çin, son yıllarda Orta ve Doğu Avrupa ülkeleri ile ekonomik ilişkilerini geliştirmiş ve ticaret hacmini artırmıştır, siyasi ve toplumsal projelerle de hedeflerini desteklemiştir. Ancak Çin'in bölgeye girişinin gecikmesi ve yarım kalan altyapı projeleri gibi nedenlerle Çin'in uzun vadeli

* Postgraduate student, Ankara Yıldırım Beyazıt University, e-mail; ahmeterenuncel0@ gmail.com, 0000-0001-67080402

** Asst. Prof. Dr, Kırşehir Ahi Evran Üniversitesi, Uluslararası İlişkiler Bölümü, e-mail:oguz.guner@ahievran.edu.tr , 0000-0003-1619-579X 


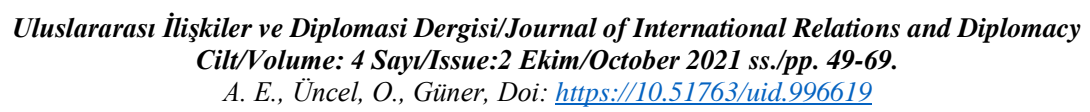

hedeflerine ulaşıp ulaşamayacağı konusunda şüpheler bulunmaktadır. Bu makale, birincil ve ikincil kaynakları inceleyerek Çin'in Orta ve Doğu Avrupa ile ekonomik, siyasi ve toplumsal ilişkilerinin potansiyeline $17+1$ bağlamında dikkat çekmeyi amaçlamaktadır. 17+1 platformunu betimleyici ve açıklayıcı bir şekilde ele alan bu çalışma, Orta ve Doğu Avrupa ülkeleri ile artan ekonomik ilişkilerin Çin'in hedeflerine yönelik tek gösterge olmayacağı, Çin'in somut projelerinin ve iradesinin hedeflerinin belirleyicisi olacağı sonucuna varıyor.

Anahtar Kelimeler: Merkez ve Doğu Avrupa, Avrupa Birliği, Çin, Kuşak ve Yol Girişimi, 17+1

\section{JEL Kodlart: F34, F35, 052}

\section{INTRODUCTION}

In recent years, relations between Central and Eastern European countries (CEE) and China have attracted attention, as has every move by China seeking to increase its influence in the world. Every move by China, which was relatively late in joining the liberal economic system established by the United States after the Cold War, has been the subject of controversy and viewed with suspicion. Although China's desire to 'return' to the countries of CEE is not new (Tubilewicz, 1999: 3-14), it found an amazing opportunity after the global financial crisis in 2008 (Vangeli and Pavlićević, 2019: 361). The first investment and trade summit between China and the countries of the region was held in Budapest in 2011, but the leaders of China and 16 other countries ${ }^{1}$ held the first 16+1 summit in Warsaw in 2012 (Vangeli and Pavlićević, 2019: 361). At this summit, China proposed twelve measures to regulate and improve its relations with CEE countries (FMPRC, 2012). The twelve measures include proposals to establish a special credit line, a fund for investment cooperation, economic and technology zones in numerous countries, and transportation networks (Song, 2019). Although the Belt and Road Initiative (BRI) was announced a year later by Chinese President Xi Jinping in 2013, 16+1 quickly became one of the pillars of the BRI (Vangeli, 2017: 109). With Greece's participation in the Dubrovnik Summit in 2019, the initiative began to be called 17+1.

On the surface, China's $17+1$ platform and relations with CEE countries can be underestimated. This is because economically, China's investment and trade volumes in the region remain modest compared to the volume of trade CEE countries have with other players such as the European Union (EU) or the United States (US). It may also be too early to see the impact of China's soft power on the region. However, a closer look reveals a very broad web of relationships, which includes regional and national government actors as

\footnotetext{
${ }^{1}$ A platform initiated by the Chinese Ministry of Foreign Affairs to boost economic relations between "China and 16 Central and Eastern European countries: Albania, Bosnia and Herzegovina, Bulgaria, Croatia, the Czech Republic, Estonia, Greece, Hungary, Latvia, North Macedonia, Montenegro, Poland, Romania, Serbia, Slovakia, and Slovenia.”
} 
well as local / provincial actors, state-owned and private enterprises, universities, think tanks, sport, health and people-to-people exchanges, and similar initiatives (Vangeli and Pavlićević, 2019: 361). The multilateral aspect of the $17+1$ format functions more like a hub and spoke model. In other words, it is a model where China is at the center and CEE countries are not contacted individually (CHOICE, 2020: 1116). Szczudlik has called this situation 'Multilateral Bilateralism' (2017: 107), which is why China's relations with CEE countries can often been seen as random, loose, and far from transparent.

The aim of this study is to provide a descriptive approach to China-CEE countries relations within the framework of the 17+1 initiative in order to better understand this network and platform and to determine China's long-term goals and possible repercussions on the region. Thus, it attempts to understand the potential of the region by stressing the importance of CEE for China and the global market. In the second part, it will take a modest look at the scope and nature of political, economic, and social relations between China and CEE countries, considering the strategic importance of the region. Lastly, the study concludes that economic indicators, political relations, and trade volumes are not sufficient parameters to interpret China's short- and long-term influence in the region. China has promised to implement or support numerous projects (infrastructure, transportation, energy, etc.) in CEE countries, and denouements of most of the projects are still unknown. China's willpower and efforts will be determinants of whether it will have longterm relations with these countries.

\section{THE SIGNIFICANCE OF CENTRAL AND EASTERN EUROPE FOR CHINA}

Relations with CEE countries are considered one of the most important points of the new Chinese diplomacy and the key aspect for BRI to keep Europe under control (Lintao; 17.07.2021). What China hopes to achieve through BRI cooperation is to strengthen cooperation in production capacities (Qiu, 2015: 3-5) and contribute to the economic growth of partner countries in specific geographical spaces and economic corridors, thus strengthening trade routes and supply chains and ensuring flow of its goods and services. Moreover, China's efforts to control world economic development and influence the globalization process (Song, 2019) differently from the hegemonic market of neoliberalism by creating new global governance principles should not be ignored.

First, China emphasizes the position of regions, regionalization, regional growth, and reducing interregional economic inequality as part of the BRI (BRF, 2015). Although China emphasizes bilateral relations with countries in the $17+1$ bloc, it needs to develop approaches to regional cooperation. To carry out this regional cooperation, a secretariat has been formed under Chinese Ministry of Foreign Affairs, and an official cooperation process has been institutionalized (CHOICE, 2020: 17-18). In parallel, most of the 
CEE countries are post-socialist states that have undergone similar economic transformations to China's. However, since most of them are economically and politically integrated with the West, they offer advantages to China as examples and testing grounds for the transition to global governance (Song, 2019).

\section{MAP 1. MEMBERS OF THE 17+1 BLOC}

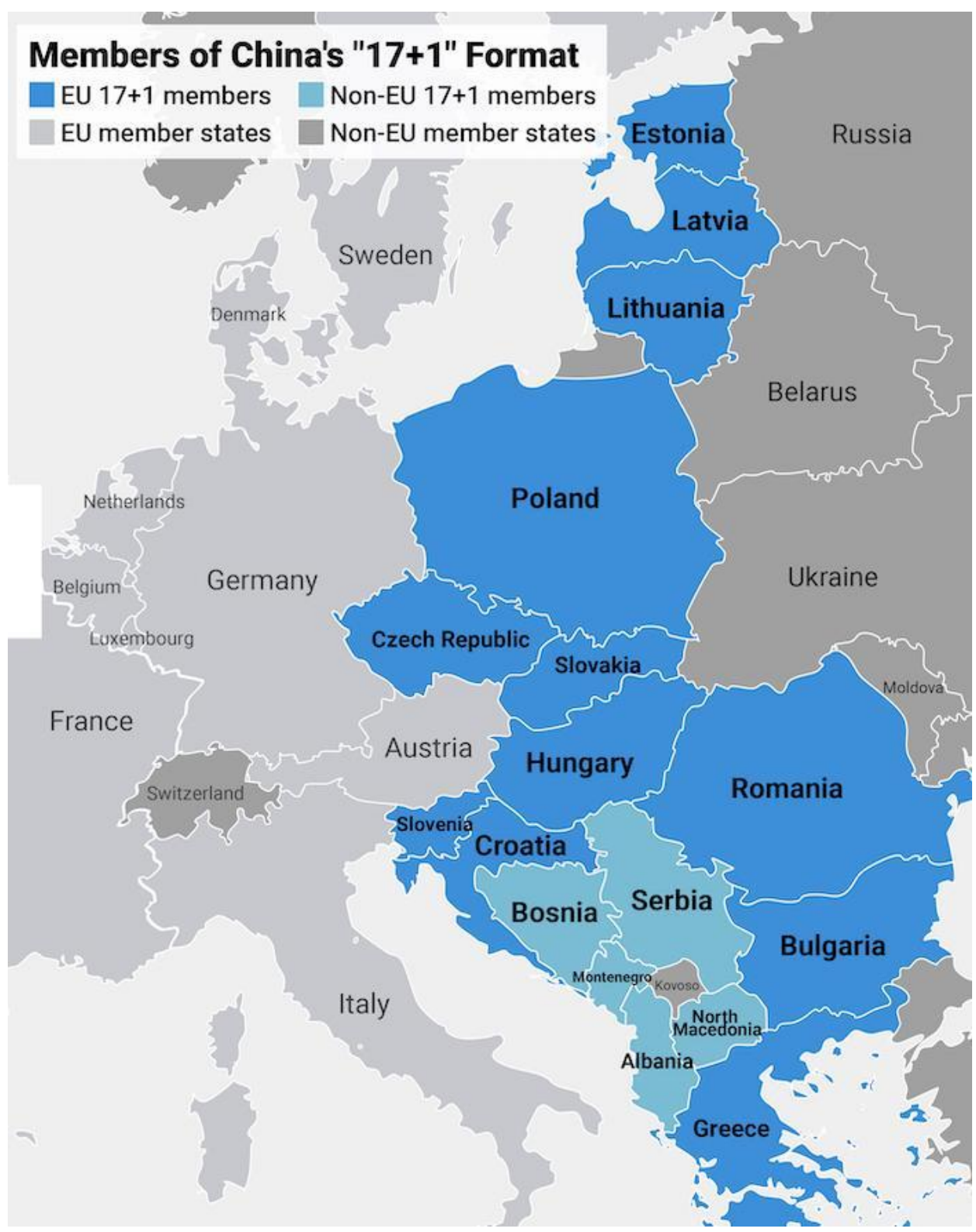

Source: https://www.echo-wall.eu/currents-context/china-out-window-cee (Access: June 22, 2021)

The CEE region is a hub for China's access to Europe and the only route through which to reach the European market (Vangeli, 2017: 104). Although the BRI does not have an official map (Godehardt, 2016: 6), it connects with CEE countries, whether using a route through Russia or through Turkey. Moreover, with 
Italy's participation in the initiative starting in 2019, the sea route through the Suez Canal coincides with the $17+1$ countries. In other words, CEE is located along the currently established or planned geographical corridors of the BRI, such as the so-called China-Mongolia-Russia Economic Corridor, the New Eurasian Land Bridge Economic Corridor, and the China-Central Asia-West Asia Economic Corridor.

The CEE countries consist of relatively developed capitalist economies and have more mature markets than regions with which China cooperates, such as Africa or Latin America (Vangeli, 2017: 104). China needs to enhance its manufacturing capacity to transition from supplying cheap, low-value goods to "export-integrated manufacturing supply chains that span the full spectrum from products technology, capital and management to services and standards." (Qiu, 2015: 12). In addition, CEE countries are showing demand for transportation and energy infrastructure projects, which China is currently pursuing. The potential for cooperation with China has attracted the interest of CEE countries, with some even vying to be China's "gateway" or "bridge" to Europe (Turcsanyi; 17.07.2021). This demand somewhat refutes the criticism of whether China wants to divide Europe. After all, China's presence there, while serving Chinese interests, is not the result of a unilateral demand. CEE countries possess a highly skilled labor force, advanced technologies, appropriate access to Western markets, and a generally secure economic environment. This has contributed to China's long- and short-term interests (Song, 2019) and attracted Chinese investors.

Fourth, the 17+1 block includes the Baltic countries ${ }^{2}$, the Balkan countries, and the Visegrád Four $(\mathrm{V} 4)^{3}$ countries, some of which are members of the EU. In this context, China and the EU are strategic partners, and the fact that China surpassed the US for the first time to become the EU's largest trading partner should not be forgotten (Global Times; 17.07.2021).

Another important point is that cooperation with non-EU CEE countries has provided a cheap place for China to learn and adapt to European regulations. This flexibility facilitates project development, not only in economic terms but also in legal terms. When considering Chinese projects in CEE countries, it is evident that more project agreements are carried out in non-EU countries, depending on the capacity of the country (CHOICE, 2020: 49). Considering that CEE countries' economic policies are highly dependent on foreign investment and China's new active policies, the resulting demand provides China with advantages in relations.

\footnotetext{
${ }^{2}$ The Baltic countries include Estonia, Latvia and Lithuania.

${ }^{3}$ An alliance between Czechia, Hungary, Poland, and Slovakia which aims to promote political, military, economic, and cultural relations.
} 
Moreover, the structure of the EU seems insufficient to take measures that include such a formation. Therefore, it is not surprising that non-EU countries are being pushed toward China. Although it is too early to see the results, a good example is the negative response to the Montenegrin Minister of Economy, who asked the EU for assistance with the Chinese highway project in Montenegro because they were unable to pay the loan installment (EUOBSERVER; 17.07.2021). The examples could be multiplied, and, at the end of the day, it can be said that internal divisions and conflicts between Member States are not created by China but are sometimes cleverly exploited.

\section{POLITICAL, ECONOMIC, AND SOCIETAL RELATIONS BETWEEN CHINA AND CEE}

\subsection{Political Relations}

Political relations have the potential to influence the EU's decision-making mechanisms regarding China in terms of the $17+1$ initiative, which includes $12 \mathrm{EU}$ member states ${ }^{4}$. These relations typically involve summits bringing together heads of government, meetings with local administrators, and multilateral events. 17+1 summits have been held in the following locations: the inaugural summit in Warsaw in 2012, Bucharest in 2013, Belgrade in 2014, Suzhou in 2015, Riga in 2016, Budapest in 2017, Sofia in 2018, and Dubrovnik in 2019.

The annual summits were strategically important for the host countries, as the Chinese Prime Minister's participation was accompanied by bilateral visits that facilitated high-profile business deals. In contrast, other participating CEE countries had a short meeting with the Chinese prime minister with no opportunity to achieve results apart from the mainly ceremonial multilateral aspects of the summits (CHOICE, 2020: 17). This helped to present the hosting of 17+1 meetings and the development of good relations with China as a matter of prestige. Regarding China, the $17+1$ platform saves costs by cultivating relations with the countries at the same time. However, participation in the forum does not affect every country equally, which causes some countries to question membership. Another problem is that mistrust toward China, particularly among the European press, is exaggerated. China has invited observers from the EU to the summits to overcome this mistrust but has not been able to achieve the desired efficiency. The main reasons are political differences as well as human rights violations. In addition, the influence of former US President Trump's rhetoric against China cannot be denied either. Some even directly described the 17+1 initiative as China's 'Trojan horse' to enter Europe (CES, 2021). When such criticisms come from CEE

\footnotetext{
${ }^{4}$ Bulgaria, Czech Republic, Croatia, Estonia, Latvia, Lithuania, Poland, Slovakia, Hungary, Slovenia, Romania and Greece.
} 


\section{Uluslararası Ilișkiler ve Diplomasi Dergisi/Journal of International Relations and Diplomacy \\ Cilt/Volume: 4 Sayl/Issue:2 Ekim/October 2021 ss./pp. 49-69. \\ A. E., Üncel, O., Güner, Doi: https://10.51763/uid.996619}

countries, they can be affected not only in bilateral relations but also in the $17+1$ platform. China is very sensitive when it comes to noninterference; for example, the 2019 China Investment Forum was cancelled due to deteriorating relations with the Czech Republic (CHOICE, 2020: 19).

The V4 countries, on the other hand, are considered the most important partners. In return, they receive the lion's share of investments and projects. Poland (Go Asia) and Hungary (Eastern Opening) even use their relationships with China as a bridge for relations with other countries in Asia (Vangeli, 2017: 111). Hungary also stands out for hosting the most China-CEE joint institutions of all participating countries (except China) $)^{5}$. Relations with the Baltic countries are developing rather cautiously, depending on relations with Russia and the EU, which are the main actors in the region. Only Latvia has hosted a summit. Although Baltic countries do not participate at a high level in the $17+1$ summits, it is seen that they have more relevant participation in meetings related to the initiative, such as those regarding tourism, agriculture, and transport. So far, four summits have been held in the Balkans, in Romania, Serbia, Bulgaria, and Croatia. Although Serbia is widely regarded as the Balkan country with the most highly extensive cooperation with China, other Balkan countries have been raising the level of cooperation to a strategic level. This is especially true for countries that are on a shaky path to EU membership (CHOICE, 2020: 22).

One of the most important parameters in terms of the region's political relations is the relationship between local political parties and the Chinese Communist Party (CCP). Although Beijing calls the 17+1 initiative an apolitical project, it has initiated a dialog with the CCP's International Liaison Department (ILD) among local governments (CHOICE, 2020: 23). While this situation shows the increasing role of the $\mathrm{CCP}$ in foreign policy and China's self-confidence, it is worth noting that party diplomacy is expanding from the communist perspective. Moreover, ILD studies have been effective in providing legitimacy to the Chinese regime and its concepts of international relations. The most notable aspect of this department is its effort to recruit local governments and political elites to build a supportive base against China. Examples can be multiplied, such as the development of the Hungarian government's relations with the CCP despite its anti-Communist origins, and Czech politicians maintaining contact with the ILD, despite warnings from the Czech Security Information Service (BIS) that it is "a specific Chinese intelligence organization" (BIS; 17.07.2021). As a result, it appears that Beijing has given party diplomacy a preeminent position in its relations with certain CEE countries, hoping to forge ties that would outlast their respective governing

\footnotetext{
${ }^{5}$ China-CEE Institute, China-CEECs Tourism Coordination Center, China-CEECs Association of Traditional Chinese Medicine, CEE Federation of Chinese Medicine Societies and China-CEECs Inter-Bank Association (CHOICE, 2020)
} 
coalitions. All in all, the level of CCP party activities in CEECs appears to be proportional to the overall level of bilateral relations (CHOICE, 2020: 26).

The reason why China attaches importance to sub-government relations and its political influence has recently emerged may be because it is late to the game compared to the existing foreign powers in the region, such as the US and Russia. China is trying to move forward without reacting and provoking major powers because of its complex relations. The US has not recognized the $17+1$ in official documents, but in 2019, former US Secretary of State Pompeo travelled to Hungary, Poland, and Slovakia to issue a warning about the presence of China and Russia in these countries (APNEWS; 17.07.2021). On the other hand, Wang Yi's visit to these countries in the following months signaled that CEE might turn out to be the new battleground (CHOICE, 2020: 30).

\subsection{Economic Relations}

The increase in trade relations with China and Chinese companies' infrastructure projects and investments in CEE countries give clues about how economic relations between China and CEE countries are formed. However, China's economic presence and trade ties and its influence over CEE countries is relatively small, and the trade deficit is growing rapidly. Despite the high value-added products that China exports to these countries, it often imports small amounts of raw materials or low value-added products from them. Infrastructure and connectivity projects, on the other hand, are created with all countries in the region, albeit very differently.

Among the 17+1 countries, the V4-Visegrád group has the highest trade flows. China's trade with the V4 countries goes back to the past, but the volume of trade has increased since 2012, especially in the last 15 years (Szunomár, Karindi and Leonte, 2020: 35). Compared to imports from China, exports have increased much less and have sometimes even decreased, leading to a rapid increase in the trade deficit. Machinery and electronic products are the main import products from China in all V4 countries. On the export side, automotive, electronic, and machinery products are considered common. Poland also exports metals such as copper alloys. Despite China's growing demand for agricultural products, very few agricultural products are exported from the V4 countries (Szunomár et al., 2020: 38).

Trade between Balkan countries and China has also increased since 2012. In contrast to the V4 countries, exports to China from Balkan countries surpassed imports from China. However, even before 2012, the difference between exports and imports was enormous, so while the trade deficit has narrowed somewhat, it still stands against Balkan countries. Although trade volumes vary across countries, Italy and Romania stand out as China's most important partners in Europe in terms of imports and exports. They are 
followed by Slovenia, Serbia, and Bulgaria as China's import partners and Croatia, Bulgaria, and Slovenia as export partners in the region. On the other hand, China is among the three main trading partners of Albania, Montenegro, and Serbia (Szunomár et al., 2020: 38). Based on UN Comtrade statistics, in the Balkan Region, Romania ranks first with a trade deficit of USD 4.425 billion, Italy second with USD 3.177 billion, and Serbia third with USD 2.075 billion (CHOICE, 2020: 38). While the products that Balkan countries import from China are similar to other CEE countries, the majority of the products they export consist of low value-added products and raw materials. Montenegro exports mostly aluminum and lead ore, which account for $94 \%$ of exports to China. North Macedonia exports ferroalloys, which account for $60 \%$ of the country's exports, to China. Chrome ores account for $86 \%$ of Albania's exports to China, while Bosnia's agricultural and textile products account for about $80 \%$. While agricultural products such as tobacco and wood account for about 50\% of Serbia's exports to China, the share of the machinery and electronics sector can be observed after the 17+1 initiative (Szunomár et al., 2020: 39). Bulgaria and Greece, which are EU member states, export low value-added products to China like other Balkan countries. On the other hand, most of Slovenia's, Croatia's, and Romania's exports consist of machinery, electronics, and vehicles and differ from other countries in this respect (Szunomár et al., 2020: 39).

A similar situation can be observed in the Baltic countries with the V4 countries. With the $17+1$ initiative, trade between the Baltic countries and China increased. Between 2012 and 2018, Latvia and Lithuania's exports to China increased by $150 \%$ and Estonia's rose by 60\% (Szunomár et al., 2020: 40). However, as the trade volume started from a very low level, it has had little impact on the deficit. On the contrary, the sharp increase in imports has made the deficit grow. The main import products of these three countries from China are electronics, industrial machinery, and textiles. On the export side, there is great diversity compared to other regions. Exports include wood, machinery, fish, minerals, metals, and textiles. In addition, since these are port countries, re-exports, or indirect exports, provide large revenues. For example, the value of re-export goods from Lithuania ${ }^{6}$ to China was EUR 48.7 million in 2017 ( Enterprise Lithuania, 2021).

\footnotetext{
${ }^{6}$ Lithuania quit the China-CEEC 17+1 group in May 2021 and urged other EU countries to abandon the initiative (Qingqing and Kunyi, 2020).
} 


\section{GRAPH 1: COMPARISON OF V4, BALTICS, AND BALKANS TRADE DATA (IN BILLIONS} USD)

\begin{tabular}{|l|l|l|l|l|}
\hline \multicolumn{2}{|c|}{ Graph 1: Comparison of V4, Baltics, and Balkans Trade Data (In Billions } \\
USD)
\end{tabular}

Source: CHOICE, 2020

Graph 1 presents China's trade relations with Baltic countries, Balkan countries, and V4 countries. According to the graph, Visegrád countries rank as the first group having the most trade deficits against China. The Visegrád group's imports from China comprise USD 68.9 billion while their export to China are relatively low, around USD 9 billion. The Balkan countries' imports from China are around USD 18.6 billion while their exports to China are USD 3.6 billion, which makes the Balkans the region with the second highest trade deficit against China. Lastly, the graph indicates that the Baltic countries' exports to China are lower than its imports. The Baltic countries' trade deficit is around -2.6 billion against China. 
Uluslararası Ilişkiler ve Diplomasi Dergisi/Journal of International Relations and Diplomacy

Cilt/Volume: 4 Sayı/Issue:2 Ekim/October 2021 ss./pp. 49-69.

A. E., Üncel, O., Güner, Doi: https://10.51763/uid.996619

Table 1: China's Import, Export, and Trade Balances with CEE Countries

\begin{tabular}{|l|l|l|l|l|l|l|}
\cline { 2 - 7 } \multicolumn{1}{c|}{} & \multicolumn{3}{c|}{ 2009 } & \multicolumn{1}{c|}{ 2019 } \\
\hline \multicolumn{1}{|c|}{ Country } & \multicolumn{1}{|c|}{ Import } & \multicolumn{1}{|c|}{ Export } & $\begin{array}{c}\text { Trade } \\
\text { balance }\end{array}$ & \multicolumn{1}{|c|}{ Import } & \multicolumn{1}{c|}{ Export } & \multicolumn{1}{c|}{$\begin{array}{c}\text { Trade } \\
\text { balance }\end{array}$} \\
\hline Albania & $64,319.83$ & 207,861 & $143,541.75$ & $103,782.65$ & $598,524.14$ & 494,741 \\
\hline $\begin{array}{l}\text { Bosnia and } \\
\text { Herzegovina }\end{array}$ & $13,562.19$ & 35,658 & $22,096.20$ & $77,040.49$ & $113,614.40$ & 36,573 \\
\hline Bulgaria & $140,997.02$ & 596,052 & $455,055.08$ & $1,163,231.22$ & $1,546,266$ & 383,034 \\
\hline Croatia & $74,856.04$ & $1,118,521$ & $1,043,665.56$ & $145,386.79$ & $1,386,437$ & $1,241,050$ \\
\hline Czech Republic & $1,131,849$ & $5,023,771$ & $3,891,922.81$ & $4,628,040.91$ & $12,911,007$ & $8,282,966$ \\
\hline Estonia & $79,331.72$ & 362,295 & $282,964.26$ & $299,411.97$ & $915,839.90$ & 616,427 \\
\hline Greece & $213,027.76$ & $3,458,064$ & $3,245,037.21$ & $726,214.33$ & $7,740,224$ & $7,014,009$ \\
\hline Hungary & $1,466,425$ & $5,343,600$ & $3,877,174.73$ & $3,747,424.14$ & $6,439,099$ & $2,691,675$ \\
\hline Latvia & $26,001.37$ & $452,298.74$ & $426,297.37$ & $195,650.99$ & $1,078,372$ & $882,721.01$ \\
\hline Montenegro & 744.64 & $76,822.60$ & $76,077.96$ & $43,304.79$ & 113,761 & $70,457.12$ \\
\hline North Macedonia & $24,093.16$ & 56,009 & $31,916.35$ & $148,704.73$ & $131,928.00$ & $-16,776.73$ \\
\hline Poland & $1,504,764$ & $7,561,767$ & $6,057,003.33$ & $3,943,810.85$ & $23,906,086$ & $19,962,275$ \\
\hline Romania & 433,095 & $2,377,287$ & $1,944,192.45$ & $2,323,744.21$ & $4,562,821$ & $2,239,077.58$ \\
\hline Serbia & 28,643 & $308,321.00$ & $279,677.78$ & $362,744.71$ & $1,025,170$ & $662,426.15$ \\
\hline Slovak Republic & 897,393 & $1,399,014$ & $501,621.50$ & $5,967,430.43$ & $2,893,893$ & $3,073,537.01$ \\
\hline Slovenia & 126,469 & 770,101 & $643,632.26$ & $516,462.42$ & $3,404,442$ & $2,887,979.68$ \\
\hline
\end{tabular}

Source: Authors' compilation based on World Bank data (https://www.worldbank.org)

As seen in the table, which reflects the import/export and trade balances between China and CEE countries, China's trade balance increased with nearly all CEE countries except for Bulgaria, Hungary, Montenegro, and North Macedonia. China's exports to these countries increased between 2009 and 2019, in some countries in particular, the level of increase exceeded expectations. Thus, it can be inferred that China's investments in the CEE region advanced between 2009 and 2019.

On the other hand, China's investments in CEE countries remain very small compared to the sum of its investment in other parts of the world. Although it is too early to see the long-term impact of the COVID-19 pandemic on China's relations with these countries, foreign direct investment had increased significantly in the last few years before the pandemic. In the distribution of these investments, one can again see the loose and unbalanced relationship between China and the CEE countries. The four Visegrád countries receive $75 \%$ of Chinese FDI in the region (CHOICE, 2020: 42). As to the reasons for this, it can be said that Chinese companies prefer EU member countries because these countries offer a safe and cheap 
way to reach the market without taxes, tariffs, and barriers. Chinese companies investing in the V4 countries are mainly interested in telecommunications, electronics, the chemical industry, and transportation. The largest investor in the region is Wanhua, which is a Chinese chemical company. Other major investors include Huawei, ZTE Corporation, Lenovo, BYD, and Comlink. Some of these companies are directly owned by the Chinese government; others are private but mostly state-owned (CHOICE, 2020: 43).

It is not possible to see a large Chinese FDI in the Balkan countries. Romania, Serbia, Greece, and Bulgaria have $80 \%$ of Chinese FDI in the Balkans; however, this share is only about a quarter of the investment in the V4 countries. As an EU member, Romania is China's leading investment country in the Balkans. There are also companies like Smithfield, Pirelli, and Nidera, which China has bought and invested indirectly in Romania. The Baltic states, on the other hand, host only 2-3\% of China's FDI. This may be because China prefers countries close to the Western European market and is interested in large investments. Estonia, Latvia, and Lithuania are relatively small and sparsely populated countries (CHOICE, 2020: 46)

In contrast to investment, China tends to target non-EU Balkan countries for infrastructure projects. This is because some of the infrastructure is weak and there are no restrictive EU principles. China is interested in these countries in projects concerning highways, construction or reconstruction, railways, and the construction or expansion of power plants. Looking at the projects, one can see the connection between $17+1$ and the BRI. Although 17+1 was established only a year ago, it has become one of the important pillars of the BRI, and the two initiatives support each other both economically and politically (Szunomár, 2019: 84-86).

The first railway between China and Europe was tested by private companies in 2008 (Hillman; 17.07.2021) and has grown exponentially since then. BRI and the $17+1$ initiative brought political support to these efforts. While there were 7 China-Europe trains in 2011, that number reached 14,000 in the first 3 months of 2019 (RAILFREIGHT; 16.07.2021). The country which has benefited the most from the ChinaEurope express so far has been Poland because 95\% of the network pass through the country's borders (RAILFREIGHT; 17.07.2021). The city of Łódź in Poland alone serves 25\% of China-Europe trains (Jakóbowski, Popławski and Kaczmarski, 2018: 10).

The CEE countries have become attractive destinations for the ever-growing number of Chinese investors and tourists. In 2018, the top three preferences of Chinese tourists in Europe were the UK (up 2.4\%), Germany (up 2.6\%) and France (up 7.7\%). However, the highest increase in the preference rate was observed in Croatia (up 45.7\%), Estonia (up 35.8\%) and Hungary (up 25.1\%) (ETC, 2019: 1). The Visegrád countries are also popular destinations for Chinese tourists. Among the developments that will increase the 
number of Chinese tourists, China called on Hungary at the 2013 Bucharest Summit to establish a platform to increase tourism ties between CEE countries and China, and the Central and Eastern European Countries' Tourism Coordination Center was established. Apart from that, most of tourism agencies in the region provide services in Chinese and organize customized tours (Szunomár et al., 2020: 53).

Beside direct flights, the V4 countries offer various visa facilitations to attract Chinese tourists to their countries, which is another reason for the increase in tourist numbers. Although direct flight opportunities in the Balkans are limited to Italy, Balkan countries are attracting Chinese tourists by easing visa requirements or introducing visa liberalization. Unlike other regions, the Baltic countries have tried to increase tourism through agreements and tenders with private companies and institutions. For example, the Estonian Tourist Board at Enterprise Estonia sought a Chinese partner to help more actively promote Estonia as a tourism destination and issued a tender in 2019 (Procurement Register; 17.07.2021). For instance, in 2017 the Latvian Investment and Development Agency signed a long-term tourism agreement with Chinese brand Alibaba Group (The Baltic Course; 17.07.2021).

\subsection{Societal Relations}

Confucius Institutes (CI) are key actors in establishing societal relations between China and CEE countries. The official purpose of these institutes is to promote Chinese language and culture abroad. Although they are similar to the national institutes of other countries in this respect, they are different from them in terms of their relationship method and structure. Confucius Institutes become part of their internal structure by establishing bilateral relationships with local universities. They are run by Hanban (Confucius Institute Headquarters), a non-profit organization, and appear impartial in this regard. However, it is worth noting that they report to the Chinese Ministry of Education (Bachulska, Bērziņa-Čerenkova, and Pejić, 2020: 57).

Before the 17+1 initiative, there were varying numbers of CIs in CEE countries. For example, the V4 countries' acquaintance with CI dates back to the 2000s. The first two were opened in Poland and Hungary in 2006. By the end of 2019, there were six CIs in Poland, two in the Czech Republic, three in Slovakia, and five in Hungary. There are also Confucius Classrooms (CCs) at various universities. Although CCs are not as large as Confucius Institutes, they have the potential to expand. Some focus more on specific areas rather than direct educational and cultural movements. For example, the Confucius Classroom at Slovak Medical University and at the University of Pecs in Hungary focuses on promoting traditional Chinese medicine (TCM) (Bachulska et al., 2020: 57). 
In contrast, CIs in the Baltic countries were opened late, and their number is small. Due to the small size of the countries and the small population, no new institutes were founded, but other universities and schools were included. In the Balkans, there were very few CIs in the early 2000s. As China's interests in the region increased, 15 new institutes were opened between 2009 and 2019. As of 2021, there are 37 CIs in CEE countries. According to the Hanban website, there are nearly 200 CIs in Europe. England leads the way with $30 \mathrm{CIs}$ and 3 CCs while Germany and France host nearly 20 CIs (DigMandarin, 2021). From this point of view, the number of CIs in CEE countries remains very modest despite the increase in recent years. It is also difficult to establish a direct link between the $17+1$ initiative and the establishment and operation of CIs. It seems to be a result of bilateral relations in line with China's strategy mentioned in the first sections.

The only official document that mentions CIs as part of the $17+1$ initiative is China's "Twelve Measures for Promoting Friendly Cooperation with Central and Eastern European Countries". Article 9 of the document supports CIs and CCs in CEE countries and invites 1000 students from each to learn Chinese in China. China has also promised to send 1000 students to CEE countries to increase joint academic studies and inter-university exchanges (FMPRC, 2012). Apart from this, however, no large-scale directives in the field of education are apparent. This may be due to doubts about the nature and impartiality of CIs.

There are also less visible but multilateral academic activities outside the institutes. For example, the China-CEECs Higher Education Institutions Consortium founded in 2014 (Lilei \& Yu, 2019: 2) brings together 134 institutes from China and CEE countries. Prestigious figures in CEE countries prefer bilateral relations with China because they have sufficient resources and connections. On the other hand, lesserknown and smaller universities prefer China-backed initiatives and consortia to expand their global networks. Of course, on the Chinese side, interest in CEE countries in higher education has increased. However, the tendency to treat Chinese academia with suspicion began to have its effect in Europe after America. One of the main reasons for this is the involvement of Chinese embassies in some educational projects. For example, Czech media reported in 2019 that a course program at a university was secretly supported by the Chinese embassy in pursuit of BRI benefits (Bajerová; 17.07.2021).

Beyond Confucius Institutes and academic exchanges, the spectrum of cultural cooperation between China and CEE is quite broad, ranging from cooperation in various fields to contacts between the publishing industry and even library cooperation, such as China-CEECs' Libraries Union Initiative (China Embassy; 22.07.2021). Cultural relations in general, like all relations with China, have the potential to cause problems but are still considered the least controversial of all CEE countries. 
Another aspect of social relations is youth cooperation. Two programs deserve special attention in the context of the 17+1 initiative: Bridge for the Future and China-CEEC's Young Political Leaders' Forum. The first targets young leaders who come to China to visit various companies and institutions and participate in events. The program is run by the All-China Youth Federation (ACYF), which operates directly under the Central Committee of the Communist Party of China ${ }^{7}$. The ACYF is highly political, with the official goal of encouraging young people to learn Marxism-Leninism and emphasizing socialism (Bachulska et al., 2020: 64). The second program is similarly subordinate to the Central Committee. One of the main goals of the International Department of the Central Committee of the Communist Party of China is to serve longterm plans by developing good relations with foreign youth who can take power in the future (Gitter and Fang; 22.07.2021). Despite their political roots, the programs can be said to have significant positive effects on young people by increasing opportunities to travel to China.

In addition to cultural activities, academic partnerships, and youth corporations, traditional Chinese medicine (TCM) occupies a very important place in the official 17+1 agenda. Although it occupies a difficult place among health practices in Europe due to legal restrictions, China continues to promote TCM as its cultural heritage. The first China-CEEC Health Ministers' Forum was held in Prague in June 2015, and its outcomes include many topics such as infectious disease surveillance, prevention, and control as well as exchanges between professionals and increasing special scholarships to increase mutual trust and understanding (NHC; 22.07.2021).

Finally, it can be observed that China has been acting more actively to improve its image in CEE countries. 2017 was officially declared the year of China-CEECs Media Cooperation and witnessed bilateral and multilateral events with many journalists visiting China and CEE countries. These events led to the signing of agreements between local broadcasters and their Chinese counterparts. In this context, China not only invests in media companies, but also invites journalists from the region to China and cooperates with PR companies. It is among the methods used by China to encourage the publication of articles and to place ambassador op-eds in the local media (The Diplomat; 17.07.2021).

\section{CONCLUSION}

China and CEE countries held the first summit in 2012, initiating the 16+1 cooperation platform aiming to develop relations and trade. Following Greece's participation, which contributed to the improvement of China's relations with the EU, the platform began to be called 17+1. After Lithuania quit

\footnotetext{
${ }^{7}$ Mass organizations in China have always been a bridge linking the CPC and government with the people. http://www.china.org.cn/english/en-sz2005/zz/zX-tt.htm (July 12, 2021)
} 
the platform, it again became 16+1. Even though there is always the possibility of a change in the number of participants, the platform aims to strengthen cooperation in economy and trade between China and the CEE countries. This study aimed to draw attention to China's interests and promise to provide impetus to economic growth in the region. The platform has been developing China's investments in the CEE countries and contributing to its new Silk Road project, which could possibly motivate other European countries to join the initiative.

Graphs and tables in this study reflect that bilateral relations with China contribute to CEE countries, even though China is in a more advantageous position, and trade volumes with these countries have exponentially increased from 2009 to 2019 , which cause the relevant studies/scholars to pay attention to China's rising influence over the region. However, economic indicators, political relations, and trade volumes are not sufficient parameters to interpret China's short- and long-term influence in the region because China promised to implement or support numerous projects (infrastructure, transportation, energy, etc.) in CEE countries, and denouements of most of the projects are still unknown. China's willpower and efforts will be determinants of whether it will have long-term relations with these countries.

Relationships in the context of the platform seem to continue to be loose and random for now, although they have potential for the future. The main reason for this is that China is already struggling with many problems. Rapid economic development has given the country a voice in the world market and on different continents. But this development has confronted China with a superpower, America. Considering China's economic breakthrough in the last 15 years, it is obvious that it will rival America in the near future, but it is still far behind militarily. If they want to protect trade routes with their economic development, they must close this gap and they are trying to do it. Disputes in the South and East China Sea, artificial islands, modernization the navy, Taiwan problem, security and stability of Xinjiang region are all efforts in this field. If you are staying in the east of Europe, the way to reach the European market is to pass through the CEE countries in one way or another. China is aware of this and is making efforts, but first of all, it must overcome the problems in its own region. Despite the reality of globalization and developing technology, we are still prisoners of our own geographies, just as Tim Marshall (2016) said. The way to overcome this conviction and establish closer relations in distant geographies is to ensure stability and security in your own region.

\section{REFERENCES}

Enterprise Lithuania (2018). Lithuania-China Bilateral Trade Review. (17.07.2021), Retrieved from https://www.verslilietuva.1t/wp-content/uploads/2018/10/2018.09.11_China_EN.pdf 
Uluslararası Ilișkiler ve Diplomasi Dergisi/Journal of International Relations and Diplomacy

Cilt/Volume: 4 Sayı/Issue:2 Ekim/October 2021 ss./pp. 49-69.

A. E., Üncel, O., Güner, Doi: https://10.51763/uid.996619

Bachulska, A., Bērzina-Čerenkova, U. A., \& Pejić, N. (2020). We the people? The challenges of societal relations with China. Prague: Association for International Affairs.

Bajerová, A. (2019). The Czech-Chinese Centre of Influence: How Chinese Embassy in Prague Secretly Funded Activities at the Top Czech University. (17.07.2021), Retrieved from https://chinaobservers.eu/the-czech-chinese-centre-of-influence-how-chinese-embassy-in-praguesecretly-funded-activities-at-the-top-czech-university/

Belt and Road Forum for International Cooperation (BRF) (2015). Full Text: Vision and actions on jointly building Belt and Road. (17.07.2021), Retrieved from http://2017.beltandroadforum.org/english/n100/2017/0410/c22-45-2.html

China Embassy (2017). Five-year Outcome List of Cooperation Between China and Central and Eastern European Countries. (22.07.2021), Retrieved from http://lt.chinaembassy.org/eng/xwdt/t1514704.htm: http://lt.china-embassy.org/eng/xwdt/t1514704.htm

China Observers in Central and Eastern Europe (CHOICE). (2020). Empty shell no more:China's growing footprint in Central and Eastern Europe. Prague: ASSOCIATION FOR INTERNATIONAL AFFAIRS (AMO).

Council for European Studies (CES) (2018). 16+1: The EU's Concerns of a Chinese 'Trojan Horse'. (22.07.2021), Retrieved from EuropeNow: https://www.europenowjournal.org/2018/06/04/161the-eus-concerns-of-a-chinese-trojan-horse/

Dig Mandarin (2021). Confucius Institutes Around the World - 2021. (12.07.2021), Retrieved from https://www.digmandarin.com/confucius-institutes-around-the-world.html

Procurement Register (2019). Eesti turismi turundamine Hiinas. (17.07.2021), Retrieved from https://riigihanked.riik.ee/rhr-web/\#/procurement/1600788/general-info

European Travel Commission (ETC). (2019). CHINESE TOURISTS FLOCK TO EUROPE. Brussels. https://etc-corporate.org/uploads/2019/03/Chinese_Tourists_Flock_to_Europe.pdf

Gitter, D., \& Fang, L. (2016). The Chinese Communist Party International Department: Overlooked yet Ever Present. (22.07.2021), Retrieved from The Diplomat: https://thediplomat.com/2016/08/thechinese-communist-party-international-department-overlooked-yet-ever-present/

Global Times. (2020). China becomes EU's largest trade partner. (17.07.2021), Retrieved from https://www.globaltimes.cn/content/1201350.shtml

Godehardt, N. (2016). No end of history. A Chinese alternative concept of international order?". Berlin: German Institute for International and Security Affairs.

Hillman, J. E. (2018). The Rise of China-Europe Railways. CSIS. (17.07.2021), Retrieved from https://www.csis.org/analysis/rise-china-europe-railways

Jakóbowski, J., Popławski, K., \& Kaczmarski, M. (2018). The Silk Railroad: The EU-China rail connections: background, actors, interests. (17.07.2021), Retrieved from https://www.osw.waw.pl/en/publikacje/osw-studies/2018-02-28/silk-railroad

Karásková, I. (2019). How China Influences Media in Central and Eastern Europe. (17.07.2021), Retrieved from The Diplomat: https://thediplomat.com/2019/11/how-china-influences-media-incentral-and-eastern-europe/

LEE, M. (2019). Pompeo warns Eastern Europe on Chinese and Russian meddling. (17.07.2021), Retrieved from AP News: https://apnews.com/article/d6639cadbde74b6d8bf2acc0e86c4550 


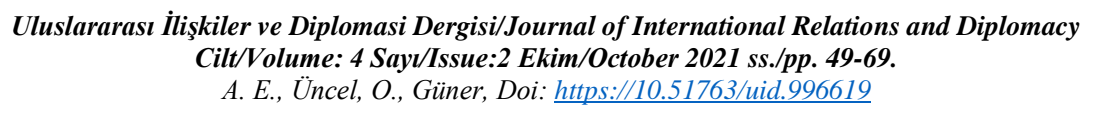

Lilei, S., \& Yu, C. (2019). People to People Communication: A case study of Education Cooperation between China and CEECs from 2006-2016. Global Economic Observer, 299-310.

Lintao, Y. (2016). Visits of opportunity: President Xi Jinping's three-state trip injects impetus into the Belt and Road Initiative. (17.07.2021), Retrieved from Beijing Review: http://www.bjreview.com/Current_Issue/Editor_Choice/201606/t20160627_800060540.html

Marshall, T. (2016). Prisoners of geography. Elliott \& Thompson.

Ministry of Foreign Affairs, the People's Republic of China (FMPRC). (2012). Ministry of Foreign Affairs, the People's Republic of China. (17.07.2021), Retrieved from https://www.fmprc.gov.cn/mfa_eng/topics_665678/wjbispg_665714/t928567.shtml

National Health Commission of the PRC (NHC). (2015). Prague Declaration on Health Cooperation and Development with Central and East Europe. (22.07.2021), Retrieved from National Health Commission of the People's Republic of China: http://en.nhc.gov.cn/2015-06/23/c_46968.htm

NIELSEN, N. (2021). EU refuses to bail out Montenegro's China loan. (17.07.2021), Retrieved from euobserver: https://euobserver.com/world/151512

Qingqing, C. \& Kunyi, Y., Lithuania's decision to quit China-CEEC 17+1 won't change fundamentals of platform, https://www.globaltimes.cn/page/202105/1224260.shtml , (23 May 2021)

Qiu, Z. (2015). The 'Triple Win': Beijing's Blueprint for International Industrial Capacity Cooperation. (17.07.2021), Retrieved from The JamesTown: https://jamestown.org/program/the-triple-winbeijings-blueprint-for-international-industrial-capacity-cooperation/

RAILFREIGHT. (2021). China-Europe Express celebrates ten year anniversary.( 09.06.2021), (16.07.2021), Retrieved from RAILFREIGHT: https://www.railfreight.com/beltandroad/2021/03/19/china-europe-express-celebrates-ten-yearsanniversary/?gdpr=deny

Schwilling, A. (2019). New Silk Road could surge to million TEU in 2025, but with subsidies. (17.08.2021) Retrieved from RailFreight: https://www.railfreight.com/specials/2019/06/04/newsilk-road-could-surge-to-million-teu-in-2025-but-with-subsidies/?gdpr=deny

Security Information Service (BIS). (2015). Annual Report of the Security Information Service for 2015. (17.07.2021), Retrieved from https://www.bis.cz/annual-reports/annual-report-of-the-securityinformation-service-for-2015-442e6079.html

Song, W. (2019). Logic of the Chinese developmental state and China's geo-economic engagement with Central and Eastern Europe. Asia Europe Journal.

Szczudlik, J. (2017). Seven years of the 16+1: An Assessment of China's 'Multilateral Bilateralism'in Central Europe. Paris: French Institute of International Relations.

Szunomár, Á. (2019). China's investments and infrastructural expansion in Central and Eastern Europe. In S. Jian, \& H. Guenter, Opportunities and challenges: sustainability of China-EU relations in a changing world (pp. 84-103). Beijing: China Social Sciences Press.

Szunomár, Á., Karindi, L., \& Leonte, A. (2020). Economic relations: A sugar cane, or a sugar-coated stick? Prague: Association for International Affairs (AMO).

The Baltic Course. (2017). Latvian Investment and Development Agency inks tourism cooperation agreement with Alibaba Group. (17.07.2021), Retrieved from http://www.balticcourse.com/eng/good_for_business/?doc=129738\&underline=chinese+tourists 
Tubilewicz, C. (1999). Comrades No More: Sino-Central European Relations after the Cold War. Problems of Post-Communism, 3-14.

Turcsanyi, R. Q. (2015). Is the Czech Republic China's New 'Bridge to Europe'? (17.07.2021), Retrieved from The Diplomat: https://thediplomat.com/2015/09/is-the-czech-republic-chinas-new-bridge-toeurope/

United Nations. (2019). 2018 International Trade Statistics Yearbook. New York.

Vangeli, A. (2017). China's Engagement with the Sixteen Countries of Central, East and Southeast Europe under the Belt and Road Initiative. China \& World Economy, 101-124.

Vangeli, A., \& Pavlićević, D. (2019). Introduction:New perspectives on China - Central and Eastern Europe relations. Asia Europe Journal, 361-368. 